\title{
Rites of Passage in Balinese Hinduism:
}

\author{
A Study on Telubulanin
}

\section{YAMAGUCHI Shinobu}

\section{Introduction}

This study aims to describe the process of a rite of passage for a three-month-old babies performed in Balinese Hinduism and to analyze its characteristics as a Hindu ritual. Hinduism was first brought by Indians to Bali in the eighth or ninth century. ${ }^{1)}$ Hinduism from Java began to spread its influence in Bali when Balinese King Dharmodayana of the Warmadewa dynasty married an eastern Javanese princess in the eleventh century. In the fifteenth century, many people from the Majapahit kingdom, the Hindu kingdom in East Java that was oppressed by Muslims, migrated to Bali. ${ }^{2)}$ At present, Hindus constitute almost ninety percent of Bali's population. Many Balinese Hindus are enthusiastic about performing rituals; thus, they can often be observed holding different types of rituals in temples and at home. I had an opportunity to observe an instance of Telubulanin, the rite of passage for three-month-old babies, performed in a Balinese Hindu family home in the Gianyar district in south central Bali. In the next section, I will describe the Telubulanin ritual process.

\section{Telubulanin Ritual Process}

\subsection{Five Ritual Categories in Balinese Hinduism}

Balinese Hinduism has five ritual categories called Panca Yadnya in Balinese language. This classification consists of the five categories: (1) Dewa Yadnya (Rituals for worshipping gods and goddesses), (2) Manusa Yadnya (Rites of passage), (3) Pitra Yadnya (Rituals for ancestors), (4) Bhuta Yadnya (Rituals for evil spirits), and (5) Rsi Yadnya (Initiation rituals for priests). Certain studies point out to pañcamahāyajña recorded in Grhyasütras and Manusmrti texts in India as the origin of Panca Yadnya. However, the period when Panca Yadnya spread in Bali remains unclear. 
The Telubulanin ritual, which is the focus of this work, is categorized under Manusa Yadnya. Manusa Yadnya is the Balinese Hinduism counterpart of Indian Hinduism's Samskāra. The two, however, differ in inclusive period. Samskāra consists of rites of passage from conception to death, whereas Manusa Yadnya includes only life events until marriage. The funeral rites in Balinese Hinduism are categorized under Pitra Yadnya. The first ritual in Manusa Yadnya is performed at the three or four months after pregnancy. The second is the birth ceremony. The third is held 42 days after the birth of the baby, and then the Telubulanin takes place 105 days or three months after birth. Another ceremony occurs 210 days after birth, followed by the tooth-filing ceremony before marriage, and then the marriage ceremony. ${ }^{3)}$

In Bali, Hindu rituals are performed according to the Balinese Uku calendar, where 1 $u k u$ is equivalent to seven days and $30 u k u$ or 210 days is considered one year. The Telubulanin ritual of 105 days after birth corresponds to half a year in the Uku calendar. The term Telubulanin means "three months" in Balinese.

\subsection{Documenting a Telubulanin Ritual}

Among the various rites of passage performed in different stages of the life cycle, Telubulanin is considered particularly important. This importance is derived from the belief that children live in heaven and are protected by gods during the first three months after their birth. Then, they come down to earth and join human society on the day of Telubulanin. They also eat solid food for the first time on this day. This practice resembles the rituals of first feeding (annaprāsana) and taking the child outside (niskramana) in Samskāra. For the above stated reasons, Telubulanin in Bali serves as both two rituals in Samskāra.

On August 14, 2014, I attended a Telubulanin ritual performed in Balinese Hindu family home in Gianyar District in south central Bali. The family members had begun the preparation of various types of offerings for the ritual three days before the ceremony. The ritual lasted two hours from 9:30 to 11:30 in the morning. The sister of the family head served as the priest (pemangku) who mainly performed the ritual. The following is the process of the ritual:

[1] Preparatory rite at the house temple

[1-1] Worship of the sun, three gods, and ancestors

[1-2] Five bows (panca sembah) 
[1-3] Pig offering as sacrifice to the gods and ancestors

[2] Main rite at Bale Dangin building

[2-1] Purification of the baby and his parents

[2-2] Worship of ancestors

[2-3] Meeting with a duck and a rooster

[2-4] Welcoming the baby to the human world

[2-5] Transmitting ancestors' power to the baby

[3] Feast

The following is a description of each process.

[1] Preparatory rite at the house temple

[1-1] Worship of the sun, three gods, and ancestors

The preparatory rite began with the female members of the family preparing offerings, such as two whole roasted pigs and ducks as well as sweets, three days before the ceremony. At the time of the preparatory rite, the said offerings were carried to the house temple. The priest first recited the phrase for worshipping the sun. Then, she purified flowers by dipping them into holy water. She used the flowers to sprinkle holy water on the ritual tools to purify them as well. After purification of tools, the parents carried their baby into the house temple. They sat on the purified space, which was sprinkled with holy water by the female assistants. After the parents were seated, the priest recited the phrase for worshipping three gods, namely, Brahma (Brahmā), Siwa (Siva), and Wisnu (Viṣnu) and their ancestors. Next was the natab, the transmittal of the power of the gods and their ancestors to the baby. The priest waved a small ritual broom called lis. The parents waved their hands as well to the baby to transmit the power of the gods and their ancestors. The last action involved the sprinkling of holy water to the baby by the priest.

\section{[1-2] Five bows (panca sembah)}

The worship of the sun, gods, and ancestors is followed by the process of the five types of bows (panca sembah). In Balinese language, panca means "five," and sembah "bowing with palms pressed together." Panca sembah is not particular to Telubulanin; it is usually performed in temples. The first bow of Panca sembah involves the purification of the worshippers' bodies as they bow down with their palms pressed together. The second bow is for worshipping Sang Hyang Widi Wasa, the god as a form of Siwa and supreme 
being in Balinese Hinduism. The third bow is for the worship of tutelary gods. The fourth is for God Samodaya and again for Sang Hyang Widi Wasa, whereas the fifth is for the thanksgiving. ${ }^{4)}$

[1-3] Pig offering as sacrifice to the gods and ancestors

The panca sembah is followed by the decapitation of two whole roasted pigs by certain participants. The pigs are then offered to the gods and ancestors. They are later consumed by the participants at the feast. The pig offering ends the preparatory rite in the house temple.

[2] Main rite at Bale Dangin building

[2-1] Purification of the baby and his parents

After the preparatory rite, the family members moved to the building called Bale Dangin for the main rite. The priest began the main rite by offering flowers to the sacrificial shrine called Pelangkiran inside Bale Dangin. God Kumara, who is identified with Indian Hinduism's Kumāra, is believed to reside at Pelangkiran and protect the children for three months after their birth. ${ }^{5}$ The priest bowed at the Pelangkiran, and worshipped the god with flowers and incense, and then recited hymns. Then, she sprinkled holy water on the offerings for purification. After the initial ritual, the parents carried their baby into Bale Dangin. The priest waved lis with her hand to transmit the power of the ancestors to the baby and then sprinkled holy water on the baby and his parents. Subsequently, the priest took the container of palm wine in her hand and poured the wine on a flower placed on the ground in front of Bale Dangin. This performance is considered to pacify the evil spirits that may disturb the ritual and to appeal to them not to do so.

[2-2] Worship of ancestors

Holding the flowers in her right hand, the priest recited phrases in front of pictures of deceased family members. ${ }^{6}$ She then sprinkled holy water on the pictures. This ritual was performed for the deceased persons in the picture but most likely included all of the family's ancestors.

[2-3] Meeting with a duck and a rooster

After the worship of ancestors, female family members carried a living duck and a rooster into Bale Dangin. The priest recited phrases while waving lis onto the duck and the rooster and then the baby. She then sprinkled holy water on the two animals and 
the baby. Afterward, the priest laid the duck's bill to the baby's mouth while his grandmother touched his mouth with cooked rice. Then, the priest touched the grandmother's palm on which cooked rice was placed, using the rooster's feet.

The duck is recognized for its ability to forage for food in garbage, whereas the rooster could clean dust on the ground by flapping its feet. Telubulanin is the ritual in which a baby eats solid food for the first time, and the actions stated above ensures that the baby will have enough food for his/her lifetime. Subsequently, the priest bowed at the pictures of deceased family members and transmitted the power of the ancestors by waving lis. The priest again pacified the evil spirits by pouring palm wine on the flower placed on the ground, which was similar to what had been described in [2-1].

[2-4] Welcoming the baby to the human world

In the courtyard, the priest first placed an unglazed bowl in which water, flowers, leaves, a duck's egg, and accessories such as a bracelet, a ring, were placed in front of Bale Dangin building. Next, the priest and the baby's grandmother put a vessel containing various offerings on the unglazed bowl. This complex mix of offerings called Penyambutan ${ }^{7)}$ is offered to three Hindu gods, namely, Brahma, Wisnu, and Siwa. The priest put palm leaves and flowers on Penyambutan and sprinkled water on it. The Penyambutan offering was later taken away from the place of ritual.

The unglazed bowl containing an egg, flowers and various types of accessories remained on the ground. The priest held the baby in her arms and dropped a flower on the ground. Then, she made the baby touch the ground with his feet three times. This action signified that the baby who had lived in heaven came down to the human world for the first time.

Subsequently, the priest washed the baby's hands using the water in the bowl. The baby's parents put the accessories in the bowl on their son. Afterward, the parents knocked the ground with a round stone and touched the baby's forehead with that stone. This action is believed to wake the gods' and ancestors' spirits; it is also a ritual to ask for protection and long life for the baby.

[2-5] Transmitting the ancestors' power to the baby

The priest, the baby, and his parents returned to Bale Dangin to perform natab. The priest worshipped their ancestors again with flowers and incense while the parents waved their hands to transmit the power of the ancestors to the baby. The baby's 
grandmother then placed a bed sheet on the ritual stand at Bale Dangin. The father held up his son, inserted a bite of cooked rice into the baby's mouth, and then dropped a few rice on the ground. $\left.{ }^{8}\right) \mathrm{He}$ then placed his son on the bed sheet that was earlier placed on the table.

After the parents lifted up their baby from the table and sat on the chairs together in Bale Dangin, the priest showed the baby certain offerings and a replica of an old Chinese coin. ${ }^{9)}$ She then transmitted the power of their ancestors by reciting phrase. During this time, the parents waved their hands to the baby. The priest concluded the main rite by offering flowers and water to the evil spirits.

[3] Feast

After the main rite ended, all participants gathered at the backyard of the house, and had lunch together. They had rice and whole roasted pork, among others which were the leftover offerings to the gods and ancestors.

\section{Conclusion}

The Telubulanin ritual I observed consisted of two parts. The first part was the preparatory rite at the house temple; the second was the main rite at Bale Dangin. In the first part of the ritual, the family members worshipped the gods and their ancestors, believed to reside at the house temple, to obtain the power from them to be used to perform the main rite. In the main rite, the ancestors' powers had been repeatedly transmitted to the baby. These actions are based on the belief that the ancestors are powerful being who give blessings to the people. The ancestors are considered equivalent to gods.

The baby was subjected to different symbolic acts, such as meeting with a duck and a rooster, touching the earth, wearing accessories, and lying on the bed alone. Through these ritual acts, he had become "a child in the human society" from being "a baby living in heaven." Thus, this ritual serves as an initiation of the child to Balinese Hindu society. The ritual also ensured that the child obtained the gods' and ancestors' protection upon entering human society. This protection was obtained through the act of touching the forehead of the child with the stone. The Telubulanin ritual clearly demonstrates Balinese Hindus' lifetime relationship with their gods and ancestors.

The Telubulanin ritual is popular among Balinese Hindus; its procedures are often 
referred in many related literature. The ritual process I observed was more flexible than fixed. ${ }^{10)}$ In the Telubulanin rituals described in books, Pemangku, the priest often recites hymns and phrases to the gods and ancestors. The hymns and phrases could be Sanskrit, Balinese, or old Javanese. ${ }^{11}$ According to Balinese Hindu ritual manuals, the hymns sung to God Kumara who is considered to protect a baby for three months after birth, are in Sanskrit, ${ }^{12)}$ as are the phrases recited at the panca sembah (five bows). ${ }^{13)}$ In contrast, certain phrases recited at the offerings are old Javanese ${ }^{14)}$ and Balinese. ${ }^{15)}$ Hence, this ritual has elements of Indian, a Javanese, and Balinese cultures.

As discussed above, the Telubulanin ritual of Balinese Hinduism is performed to feed a baby with solid food and make him step on the earth for the first time. This ritual is considered an initiation rite for a baby to enter Balinese Hindu society. Although the ritual process has distinct difference from Indian Hinduism's Samskära, the phrases recited in the ritual contain Indian elements, along with Javanese, and local Balinese ones. The structure of the three elements mentioned above in Balinese Hindu rituals, as well as their inclusion, merits future research. I hope to present this issue in my next paper.

\section{Notes}

1) See Takashima 1992, 61.

2) See Yamaguchi 2002, 53; Yamaguchi 2003, 15.

3) On the rites of passage in Balinese Hinduism, see Swellengrebel 1984, 57-58.

4) See Suhardana 2008, 17-31.

5) This description is provided by Mr. I Ketut Wiana, former secretary general of Parisada Hindu Dharma Indonesia Pusat.

6) Two pictures of the deceased persons were displayed on the wall of Bale Dangin. According to the head of the household, one was of his mother and the other was of his elder brother.

7) The word penyambutan is derived from the Indonesian word sambut (to welcome). Penyambutan is referred here as the offerings for welcoming the baby who has come down from heaven to human world.

8) The dropped rice is to be shared among Kanda Empat, which means four brothers or sisters. They are believed to accompany the Balinese Hindus when they are born. According to Eiseman Jr. $(1990,100)$, they are the personifications of four items attached to a child during birth: blood, amniotic fluid, vernix, and placenta.

9) Mr. I Wayan Joni Artha, a former graduate student at Institut Hindu Dharma Negeri Denpasar recounted a Balinese legend of a Chinese princess married to a Balinese king in the old times. 
Minagawa $(2014,118-122)$ referred to the circulation history of Chinese coins in Bali that could be attributed for the inclusion of Chinese coins in the rituals.

10) I Made Sujana and I Nyoman Susila $(2007,5)$ described a different process. Their description does not include the act of meeting with a duck and a rooster, although Penyambutan offering to welcome the baby is present.

11) Mr. I Ketut Darna told me that his sister, the priest, recited nearly all the phrases in Balinese. He is the head of the household that performed the Telubulanin I observed in 2014.

12) See I Wayan Watra 2006, 64-65. Gourdriaan and Hooykaas (1971, 287-288) provided similar phrases on the manuscript of palm leaves.

13) See Suhardana 2008, 17-33.

14) See I Made Sujana and I Nyoman Susila 2007, 13.

15) See I Made Sujana and I Nyoman Susila 2007, 39.

\section{Bibliography}

Eiseman Jr., Fred B. 1990. Bali Sekala and Niskala. Singapore: Tuttle.

Gordrian, T., and C. Hooykaas. 1971. Stuti and Stava. Amsterdam: North-Holland Publishing.

I Made Sujana, and I Nyoman Susila. 2007. Manggala Upacara. Surabaya: Pāramita.

I Wayan Watra. 2006. Mantra dan Belajar Aneka Mantra. Surabaya: Pāramita.

Minagawa Kōichi 皆川厚一. 2014. “Indoneshia, Bari shakai ni oite Chūgoku yurai to sareru ikutsuka no bunkateki jirei ni tsuite”インドネシア，バリ社会において中国由来とされるい くつかの文化的事例について. Kokusai jōmin bunka kenkyū sōsho 国際常民文化研究叢書 7: 115-138.

Suhardana, K. M. 2008. Pūjā Tri Sandhyā, Kramaning Sembah, Kidung Dewa Yajña. Surabaya: Pāramita.

Swellengrebel, J. L. 1984. Introduction to Bali: Studies in Life, Thought, and Ritual, 3-76. Dordrecht: Foris Publication.

Takashima Jun 高島淳. 1992. “Hindū bunka to shite no Bari”ヒンドゥー文化としてのバリ.In Kamigami no shima Bari 神々の島バリ, ed. Kōno Ryōsen 河野亮仙, 59-70. Tokyo: Shunjūsha.

Yamaguchi Shinobu 山口しのぶ. 2002. “Bari-Hindūkyō no kamigami”バリ・ヒンドゥー教の 神々.Chükyō Joshi Daigaku Ajia Bunka Kenkyūjo ronshū 中京女子大学アジア文化研究所論集 4: 53-100.

2003. "Bari-Hindū jiin no shinzō ni tsuite: Batuburan-pusa jiin no jirei hōkoku"バリ・ヒン ドゥー寺院の神像について: バトゥブラン・プサ寺院の事例報告. Mikkyō zuzō 密教図像 22: $15-26$.

Key words Balinese Hinduism, Hindu ritual, pañcamahāyajña

(Professor, Toyo University, PhD) 